\title{
Visualization of a spinal capillary telangiectasia with 2D DSA and cone-beam CT
}

Figure Radiologic images of capillary telangiectasia

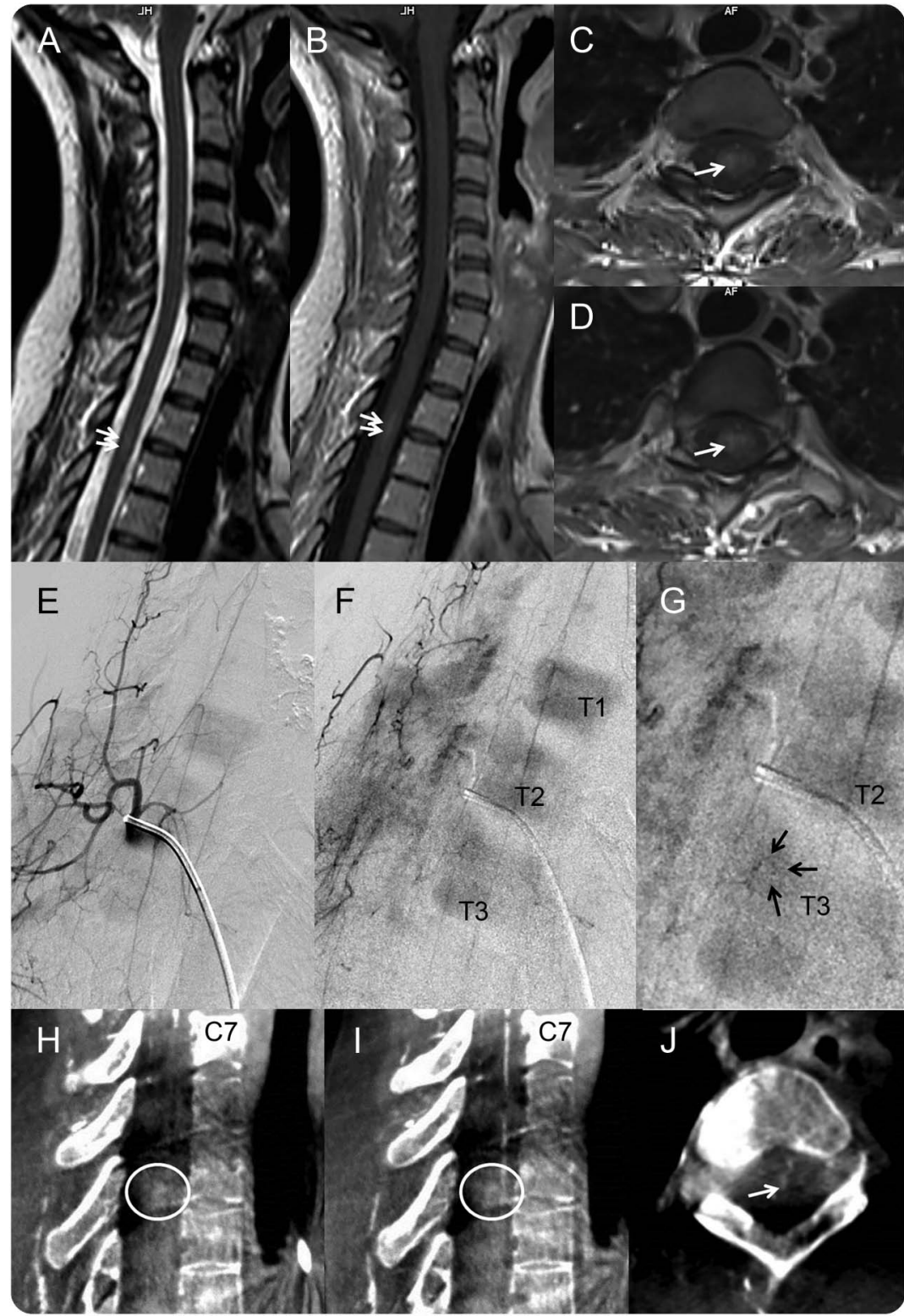

Sagittal and axial T2-T1-weighted images show focal spinal cord hyperintensity (double arrows; A) and subtle enhancement (double and singular arrows; B-D) at T2-T3 on the right side (mimicking a demyelination plaque). Spinal angiogram (E-G) and Dyna-CT MIP reconstructions ( $\mathrm{H}-\mathrm{J}$; white circle and arrow) show capillary telangiectasia at the same level.

A 30-year-old woman complained of right lower limb hypoesthesia for a year. She had 2 MRI studies (figure, A-D). CSF and evoked potentials were normal. We suspected capillary-venous diseases ${ }^{1}$ and performed a spinal angiographic examination completed with Dyna-CT (AXIOM-Artis-Zee Biplane Angiosuite; Siemens Medical Solutions, Erlangen, Germany) during the manual injection of right deep cervical artery. ${ }^{2}$ The $2 \mathrm{D}$ angiographic 
images showed a superficial circle in the spinal cord at T2-T3 in late phases of injection (figure, E-G). This finding was confirmed in sagittal and axial Dyna-CT MIP reconstructions (figure, $\mathrm{H}-\mathrm{J}$ ); the final diagnosis was capillary telangiectasia.

Giuseppe Faragò, MD, Silvia Rossi, MD, Alessandra Erbetta, $M D$

From the Neuroradiology Department (G.F., A.E.) and Neuroimmunology and Neuromuscular Diseases Unit (S.R.), IRCCS Fondazione Istituto Neurologico Carlo Besta, Milan, Italy.

Author contributions: Dr. Faragò: study concept and design, acquisition of data. Dr. Rossi: critical revision of manuscript for intellectual content. Dr. Erbetta: study supervision.

Study funding: No targeted funding reported.

Disclosure: The authors report no disclosures relevant to the manuscript. Go to Neurology.org for full disclosures.

Correspondence to Dr. Faragò: giuseppe.farago@istituto-besta.it

1. Gross BA, Puri AS, Popp AJ, Du R. Cerebral capillary telangiectasias: a meta-analysis and review of the literature. Neurosurg Rev 2013;36:187-193.

2. Faragò G, Caldiera V, Antozzi C, Bellino A, Innocenti A, Ciceri E. Automated double-cone-beam CT fusion technique: enhanced evaluation of glue distribution in cases of spinal dural arteriovenous fistula (SDAVF) embolisation. Eur Radiol 2017;27:2200-2205.

\section{Subspecialty Alerts by E-mail!}

Customize your online journal experience by signing up for e-mail alerts related to your subspecialty or area of interest. Access this free service by visiting Neurology.org/site/subscriptions/etoc.xhtml or click on the "E-mail Alerts" link on the home page. An extensive list of subspecialties, methods, and study design choices will be available for you to choose from-allowing you priority alerts to cutting-edge research in your field!

\section{Visit the Neurology ${ }^{\circledR}$ Resident \& Fellow Website}

Click on Residents \& Fellows tab at Neurology.org.

Now offering:

- Neurology ${ }^{\circledR}$ Resident \& Fellow Editorial team information

- "Search by subcategory" option

- E-pearl of the Week

- RSS Feeds

- Direct links to Continuum ${ }^{\circledR}$, Career Planning, and AAN Resident \& Fellow pages

- Recently published Resident \& Fellow articles

- Podcast descriptions

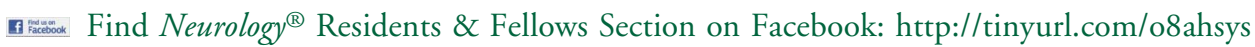

twitter Follow Neurology ${ }^{\circledR}$ on Twitter: http://twitter.com/GreenJournal 


\title{
Neurology
}

\author{
Visualization of a spinal capillary telangiectasia with 2D DSA and cone-beam CT \\ Giuseppe Faragò, Silvia Rossi and Alessandra Erbetta \\ Neurology 2017;89;2395-2396 \\ DOI 10.1212/WNL.0000000000004719
}

This information is current as of December 4, 2017

Updated Information \& Services

References

Subspecialty Collections

Permissions \& Licensing

Reprints including high resolution figures, can be found at: http://n.neurology.org/content/89/23/2395.full

This article cites 2 articles, 0 of which you can access for free at: http://n.neurology.org/content/89/23/2395.full\#ref-list-1

This article, along with others on similar topics, appears in the following collection(s):

All Demyelinating disease (CNS)

http://n.neurology.org/cgi/collection/all_demyelinating_disease_cns Arteriovenous malformation

http://n.neurology.org/cgi/collection/arteriovenous_malformation Cerebrospinal Fluid

http://n.neurology.org/cgi/collection/cerebrospinal_fluid

MRI

http://n.neurology.org/cgi/collection/mri

Information about reproducing this article in parts (figures,tables) or in its entirety can be found online at:

http://www.neurology.org/about/about_the_journal\#permissions

Information about ordering reprints can be found online:

http://n.neurology.org/subscribers/advertise

Neurology ${ }^{\circledR}$ is the official journal of the American Academy of Neurology. Published continuously since 1951, it is now a weekly with 48 issues per year. Copyright @ 2017 American Academy of Neurology. All rights reserved. Print ISSN: 0028-3878. Online ISSN: 1526-632X.

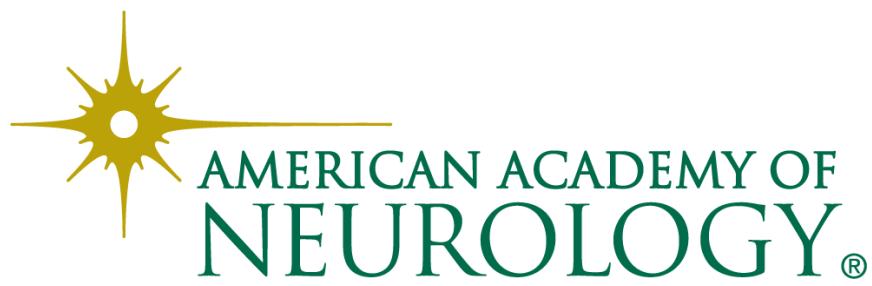

